\title{
Rapid exacerbation featuring acute leukemoid reaction after retrolaparoscopic nephrectomy: a rare case report of renal cell carcinoma with postoperative comprehensive genomic profiling
}

\author{
Xuhui Zhang ${ }^{1 *+}$ (D), Lijuan Yan ${ }^{2+}$, Xiaobin Yuan ${ }^{1}$, Tao Bai ${ }^{3}$, Lei Zhang ${ }^{1}$ and Shuaihong Han ${ }^{1}$
}

\begin{abstract}
Background: Rapid lethal exacerbation and recurrence featuring acute leukemoid reaction (ALR) after retrolaparoscopic radical nephrectomy (RN) is a relatively rare clinical incident. Performing the reoperation for the patient and analyzing the tissue-based genetic mutation information postoperatively are a skill-demanding and meaningful task, which have been even more rarely reported.

Case presentation: We present a case with a large right renal mass $(13.0 \times 10.0 \times 8.0 \mathrm{~cm})$. This 71 -year-old male patient underwent the retrolaparoscopic RN in our department. The operation was technically precise and successful with final pathological diagnosis of hybrid (clear cell and papillary type) renal cell carcinoma (RCC). However, 10 days after the patient was discharged, he was readmitted with the chief complaint of high fever with severe right flank pain. CT scanning revealed that right retroperitoneal hematoma and the blood routine showed the dramatic elevation of white blood cell count (WBC). Even though the immediate broad-spectrum antibiotics were administered without delay and subsequent percutaneous puncturing and drainage was performed, the patient's condition still exacerbated rapidly. In spite of the reoperation of hematoma evacuation, the patient died of multiple organ failure 10 days after the reoperation. The pathological result of reoperation showed the necrotic and hematoma tissue blended with RCC tumor cells (nuclear grading III), and both of the postoperative tissueoriginated comprehensive genomic profiling by using the specimens from the RN and reoperation respectively indicated significant mutations of some oncogenes which might have potential relevance with ALR. Besides, both of the immunohistochemical $(\mathrm{IHC})$ staining results from primary surgical renal mass and reoperative resected tissue revealed the positive expressions of granulocyte colony-stimulating factor (G-CSF).

(Continued on next page)
\end{abstract}

\footnotetext{
* Correspondence: xuhuizhangurology@126.com

${ }^{+}$Xuhui Zhang and Lijuan Yan contributed equally to this work.

'Department of Urology, First Hospital of Shanxi Medical University, No. 85, Jiefangnan Road, Taiyuan 030001, Shanxi, China

Full list of author information is available at the end of the article
}

(c) The Author(s). 2020 Open Access This article is licensed under a Creative Commons Attribution 4.0 International License, which permits use, sharing, adaptation, distribution and reproduction in any medium or format, as long as you give appropriate credit to the original author(s) and the source, provide a link to the Creative Commons licence, and indicate if changes were made. The images or other third party material in this article are included in the article's Creative Commons licence, unless indicated otherwise in a credit line to the material. If material is not included in the article's Creative Commons licence and your intended use is not permitted by statutory regulation or exceeds the permitted use, you will need to obtain permission directly from the copyright holder. To view a copy of this licence, visit http://creativecommons.org/licenses/by/4.0/. The Creative Commons Public Domain Dedication waiver (http://creativecommons.org/publicdomain/zero/1.0/) applies to the data made available in this article, unless otherwise stated in a credit line to the data. 
(Continued from previous page)

Conclusions: ALR may be a predictor of poor prognosis in patients with RCC, and comprehensive genomic profiling as well as the alterative expression of G-CSF can help to provide potential valuable genetic etiological information and evidence for guiding the potential effective molecular-targeting therapy.

Keywords: Renal cell carcinoma, Acute leukemoid reaction, Comprehensive genomic profiling, Gene mutation, Granulocyte colony-stimulating factor

\section{Background}

As the third most common malignancy in the genitourinary system, renal cell carcinoma (RCC) affects about nearly $3 \%$ of all adult malignancies [1] and led to 14,400 tumor-related death events and 63,990 new diagnosed cases in the USA last year [2]. For the last three decades, the survival improvement of RCC mainly attributed to the timely implementation of surgical interventions, especially the laparoscopic surgery [3, 4]. Acute leukemoid reaction (ALR) is defined as reactive leukocytosis exceeding $40 \times 10^{9} / \mathrm{L}$, with a significant increase in early neutrophil precursors, and can be a paraneoplastic manifestation of various malignant tumors [5]. ALR has been reported in tumors of the stomach, colon, liver, gall bladder, pancreas, lung, bladder, bone, and thyroid gland [6-11]. There are a few published papers that described ALR in patients with renal mass [12-14], but the authors only focused on the clinical findings with the absence of subsequent genetic mutation analysis. Here, we present a rare case of a large renal tumor $(13.0 \times 10.0 \times$ $8.0 \mathrm{~cm}$ ) with postoperative ALR and rapid lethal deterioration featuring the tissue-originated comprehensive genomic profiling. To our knowledge, our case is the first report that combined the perioperative clinical description with the genetic investigation by far.

\section{Case presentation}

A 71-year-old male patient was admitted into our hospital with chronic right flank pain. The abnormal computed tomography (CT) image presentation of right renal mass, revealed by occasional health examination, accompanied with the complaint of intermittent nausea. Besides, his past medical history also included diabetes mellitus (type 2) for 10 years and significant hypertension for 12 years, ranging from 140-160/90-95 mmHg, fluctuated periodically. Regular combined subcutaneous injection of short-acting insulin and insulin glargine was recorded for the treatment of diabetes mellitus, and the patient claimed that the serum glucose level was controlled satisfactorily all the time. As for hypertension, nifedipine sustained-release tablets were prescribed as the oral therapy by the physician, but the patient admitted that he failed to follow the long-term regular medication.
The patient's height was $171.0 \mathrm{~cm}$, and the body weight was $65.0 \mathrm{~kg}$. The BMI was $22.23 \mathrm{~kg} / \mathrm{m}^{2}$. The laboratory tests presented the elevated level of white blood cell $(W B C)$ count $\left(29.9 \times 10^{9} / \mathrm{L}\right)$. The red blood cell (RBC) count and other vital parameters were all within the reference range.

As for the medical image examinations, the routine chest X-ray image did not reveal the abnormal findings. The strong and heterogeneous enhancement pattern from the dual-source 64-slice enhanced CT-scanned films including arterial phase, venous phase, and excretory phase indicated the radiologic diagnosis of right malignant renal tumor with the size of $13.0 \times 10.0 \times 8.0 \mathrm{~cm}$ (Fig. 1a) [15].

In order to facilitate the surgical orientation and improve the manipulating accuracy, the data from CT images was extracted, and the three-dimensional digital model (3D-DM) was reconstructed. The copied information was analyzed and reconstructed into the 3D-DM by using a postprocessing software named threedimensional medical image reconstructing and guiding system (3D-MIRGS, China). The retroperitoneal space along with critical anatomic structures including renal tumor, the relevant vasculature, the kidney, and the renal collecting system on the affected side were reconstructed and marked by using different colors simultaneously (Fig. 1b).

The retrolaparoscopic $\mathrm{RN}$ was performed under the assisted navigation of 3D-DM at the Department of Urology. The right kidney along with the right adrenal gland was dissected and excised completely. The hemostasis was achieved carefully.

The operative time was $1 \mathrm{~h}$ and $30 \mathrm{~min}$, with no intraoperative complications happened. The estimated blood loss was about $20 \mathrm{~mL}$. The size of resected tumor was $10.0 \times 8.0 \times 6.0 \mathrm{~cm}$. The final pathological diagnosis was hybrid (clear cell and papillary type) renal cell carcinoma (nuclear grading III) (Fig. 2a, b). WBC count fell back to the level of $10.6 \times 10^{9} / \mathrm{L}$ at the first day postoperatively, which further dropped down to $7.3 \times 10^{9} / \mathrm{L} 2$ days later. The recovery course was uneventful, and the patient was discharged after 7 days postoperatively.

Ten days after the patient was discharged, he was readmitted with the chief complaint of high fever with severe right flank pain. CT scanning revealed that right 

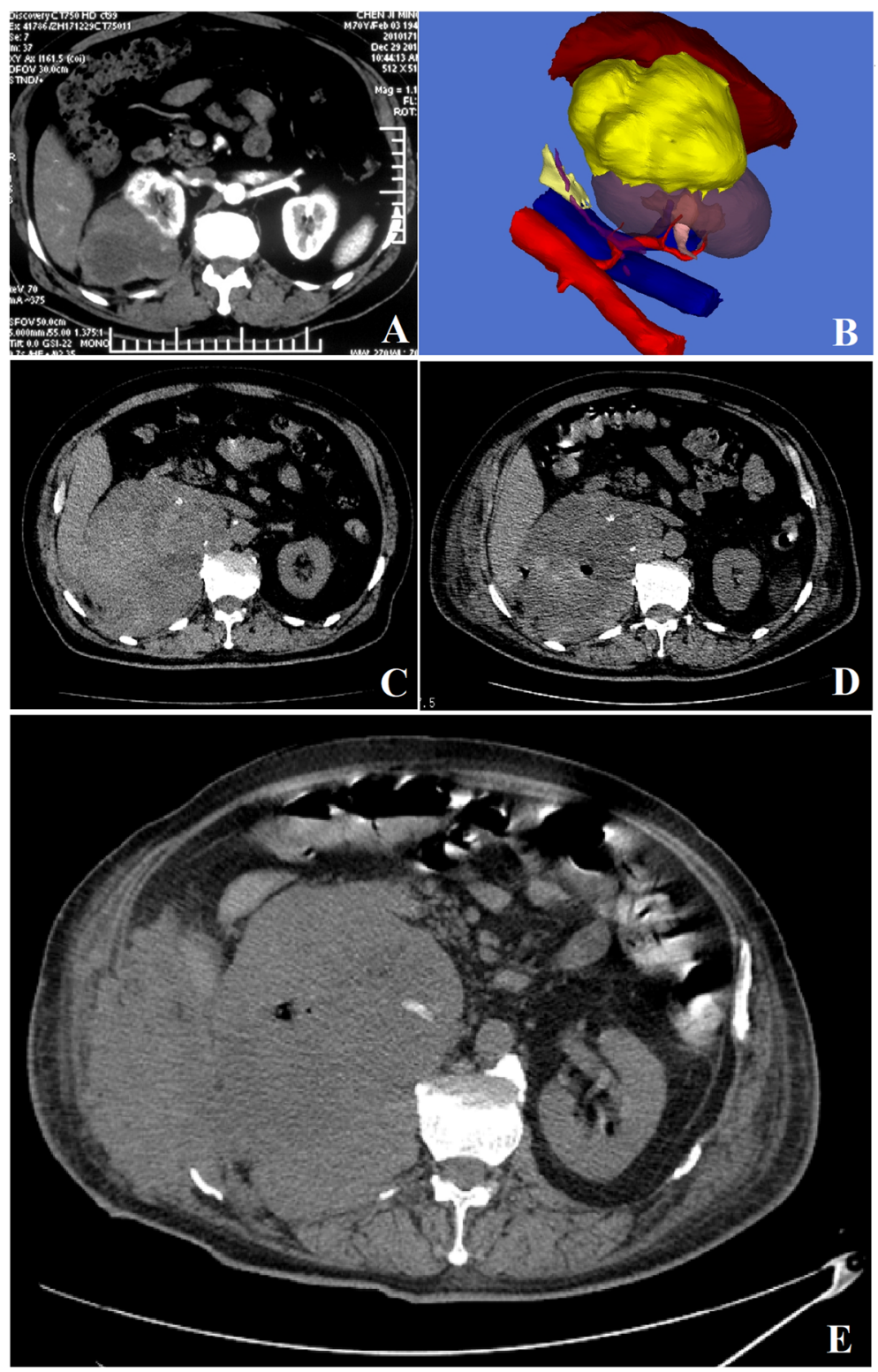

Fig. 1 a The primary $C T$ findings when admission showed the right renal mass with the size of $13.0 \times 10.0 \times 8.0 \mathrm{~cm}$. $\mathbf{b}$ The reconstructed threedimensional digital model (3D-DM) marked by using different colors (yellow color: the renal mass). c The rechecked $C T$ findings when readmission showed a right retroperitoneal hematoma with the size of $16.3 \times 13.2 \times 10.4 \mathrm{~cm}$. $\mathbf{d}$ The rechecked CT scanning result after the percutaneous puncturing and drainage showed no significant shrinkage for the retroperitoneal hematoma. e The day before his clinical death, the rechecked $C T$ scanning images showed that the rapid retroperitoneal cavity metastasis with obvious sign of puncturing track implantation

retroperitoneal hematoma (Fig. 1c) and the blood routine showed the dramatic elevation of WBC count $(96.3$ $\left.\times 10^{9} / \mathrm{L}\right)$. At the same time, the body temperature was high $\left(37.9\right.$ to $40.5^{\circ} \mathrm{C}$ ). ALR was established. He was treated with systemic antibiotics and the temperature decreased, but the WBC count still remained on high level. After the consultation of multi-disciplinary team and department discussion, we decided to perform the percutaneous puncturing and drainage for him after a 5day systemic antibiotic therapy. Even though there was bloody drainage fluid with the amount of about $300 \mathrm{~mL}$ each day, the patient's condition still exacerbated rapidly and the $\mathrm{CT}$ scanning result showed no significant shrinkage for the retroperitoneal hematoma (Fig. 1d). Five days after the drainage, the patient's symptom of right flank swelling and pain still aggravated significantly. In spite of the immediate reoperation of hematoma evacuation, the patient died of multiple organ failure 10 days after the reoperation eventually. The day before his clinical death, the rechecked CT scanning 


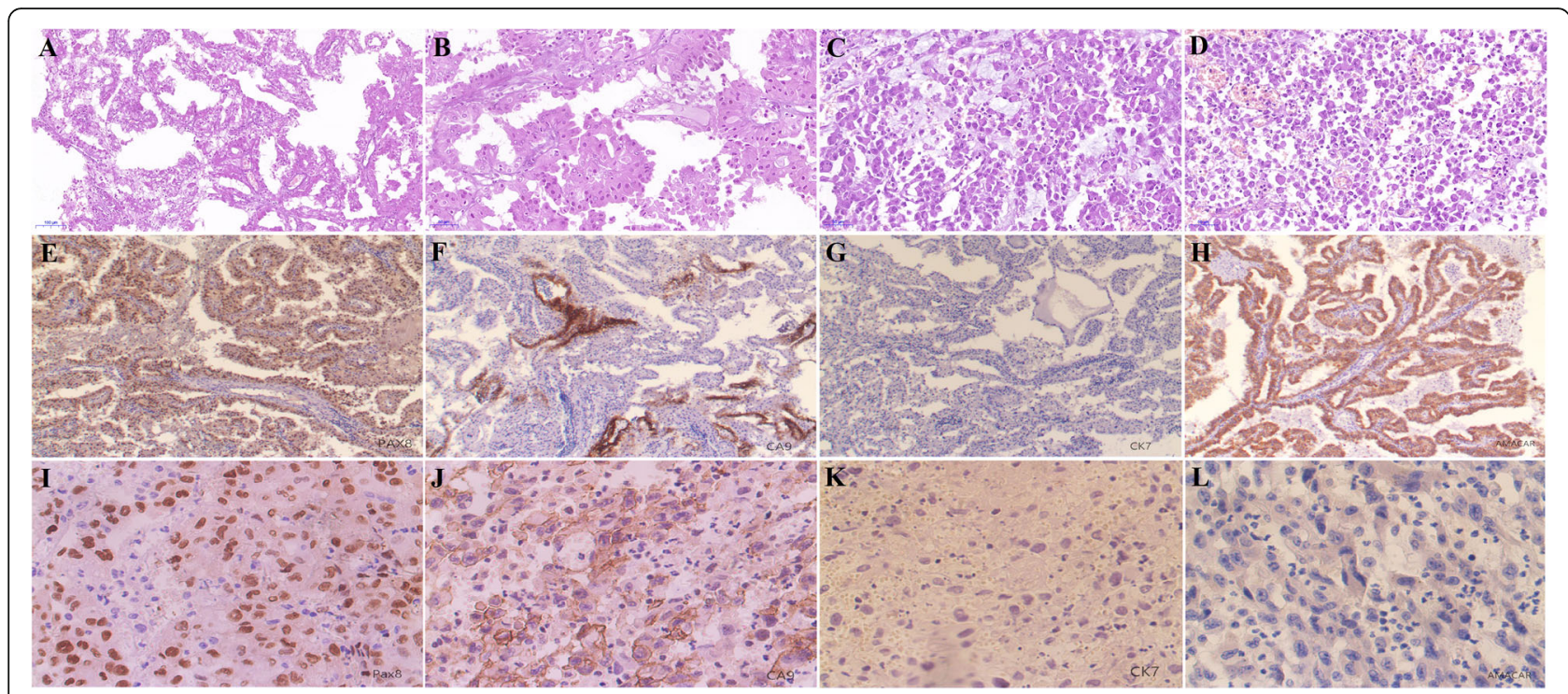

Fig. $\mathbf{2}$ a, b The pathological diagnosis of first operation was hybrid (clear cell and papillary type) renal cell carcinoma (nuclear grading III). $\mathbf{c}$, d The final pathological result of reoperation showed the necrotic and hematoma tissue blended with RCC tumor cells (nuclear grading IV). $\mathbf{e}-\mathbf{h}$ The results of immunohistochemical staining from the specimens of 1st operation. (e Pax8, $\mathbf{f} C A 9, \mathbf{g} C K 7$, and $\mathbf{h}$ AMACAR). i-I The results of immunohistochemical staining from the specimens of 2nd operation. (i Pax8, j CA9, k CK7, and I AMACAR)

images showed the rapid retroperitoneal cavity metastasis with obvious sign of puncturing track implantation (Fig. 1e). From the admission to clinical death, the trend of WBC counts can be seen in Fig. 3.

The final pathological result of reoperation showed the necrotic and hematoma tissue blended with RCC tumor cells (nuclear grading IV) (Fig. 2c, d). Furthermore, the immunohistochemical staining from the specimens of two operations was performed to evaluate the expressions of 4 markers. Primary antibodies used in the study included paired box 8 (Pax8) (Santa Cruz Biotechnology sc-514352, Dallas, TX, USA), carbonic anhydrase 9 (CA9) (Santa Cruz Biotechnology sc-365900, Dallas, TX, USA), cytokeratin 7 (CK7) (Santa Cruz Biotechnology sc-23876, Dallas, TX, USA), and $\alpha$-methylacyl-coenzyme A racemase (AMACAR) (Santa Cruz Biotechnology sc515623, Dallas, TX, USA). UltraView ${ }^{\mathrm{Tm}}$ DAB detection kit was purchased from Ventana (Arizona, America). All immunohistochemistry assays were performed on the Roche BenchMark XT fully automatic IHC/ISH instrument by optimized protocols. The results of immunohistochemical staining from the specimens of two operations all indicated that the tumor cells were immunopositive for Pax8 and CA9, but negative for CK7 and AMACAR (Fig. 2e-1).

After the death of the patient, we retrieved part of the surgical specimens from two operations he underwent and delivered them to a biochemical company

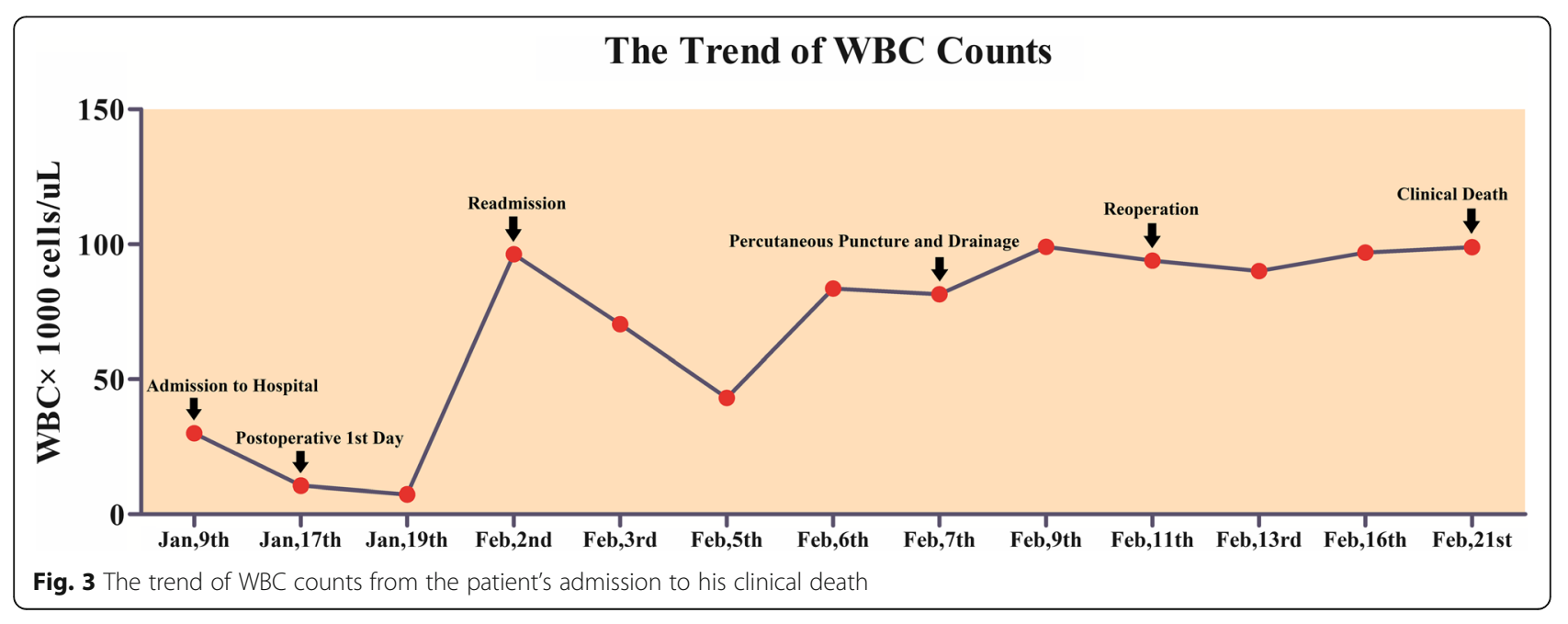




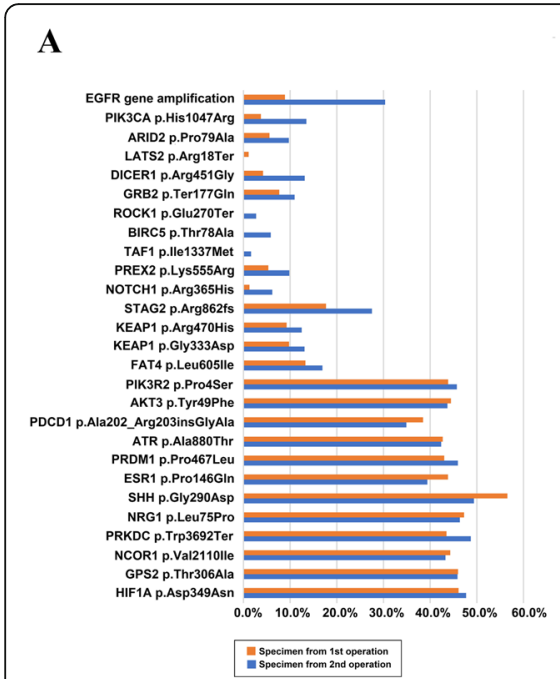

B

Fig. 4 The analysis of postoperative comprehensive genomic profiling. a The summary of gene mutation abundance indicated that most of the gene mutation abundance from the specimen of reoperation was higher than the specimen of primary operation. $\mathbf{b}$ The mutation was divided into 8 clones (0-7) according to the information of mutation abundance and mutation types. Most clones of reoperation specimen were derived from the primary tumor specimen, and some added clones can be seen (marked in red frame), indicating that the metastases evolved from the primary foci

(Life Healthcare, China) which provides the service of genetic testing. Both of the postoperative tissueoriginated comprehensive genomic profiling by using the specimens from the $\mathrm{RN}$ and reoperation respectively indicated significant mutations of several genes (Fig. 4 and the detailed data of comprehensive genomic profiling is shown in Supplemental. 1). There are 7 genes' mutation abundance that showed a statistical difference between two operations' specimens, featuring the most dramatic elevated mutation of phosphatidylinositol-4,5-bisphosphate 3-kinase catalytic subunit alpha (PIK3CA) and epidermal growth factor receptor (EGFR) (Table 1 and Fig. 5).

Given some cases of G-CSF-producing RCC with leukemoid reactions have been reported previously $[14,15]$, the IHC for assessment of G-CSF expression in the renal tumor and in the specimen from the reoperation were performed on formalin-fixed paraffin-embedded tissue blocks. The blocks were sectioned into $4 \mu \mathrm{m}$ and pretreated using PT Link (Dako, Glostrup, Denmark) with EnVisionTM FLEX Target Retrieval Solution High pH (Dako) containing Tris/ EDTA buffer at pH 9.5. All washing was performed with EnVision FLEX Wash Buffer pH7.75 (Dako). Staining was performed according to the manufacturer's protocol (Dako). The samples were incubated with the primary mouse monoclonal anti-G-CSF antibody (Santa Cruz Biotechnology sc-53292, Dallas, TX, USA) at dilution 1:50 for $30 \mathrm{~min}$. The secondary antibody incubation time was $15 \mathrm{~min}$. All detection reagents were from the EnVision FLEX series by Dako (secondary antibodies, EnVision FLEX HRP, and EnVision FLEX Substrate Buffer). The slides were counterstained with hematoxylin (EnVision FLEX

Table 1 Outcomes of postoperative tissue-originated comprehensive genomic profiling

\begin{tabular}{|c|c|c|c|c|}
\hline \multirow[t]{2}{*}{ Genes } & \multirow[t]{2}{*}{ Mutation types } & \multirow[t]{2}{*}{ Mutation sites } & \multicolumn{2}{|c|}{ Mutation abundance } \\
\hline & & & 1st operation & 2nd operation \\
\hline PIK3CA & missense mutation & exon21 & $3.73 \%$ & $13.46 \%$ \\
\hline$E G F R$ & gene amplification & - & 8.86 copies & 30.33 copies \\
\hline NOTCHI & missense mutation & exon6 & $1.27 \%$ & $6.15 \%$ \\
\hline FAT4 & missense mutation & exon1 & $13.26 \%$ & $16.89 \%$ \\
\hline STAG2 & frameshift mutation & exon26 & $17.66 \%$ & $27.51 \%$ \\
\hline ATR & missense mutation & exon13 & $42.68 \%$ & $42.34 \%$ \\
\hline PRKDC & nonsense mutation & exon77 & $43.48 \%$ & $48.69 \%$ \\
\hline
\end{tabular}

PIK3CA phosphatidylinositol-4, 5-bisphosphate 3-kinase catalytic subunit alpha; EGFR epidermal growth factor receptor; NOCTH1 notch homolog 1; FAT4 FAT atypical cadherin 4; STAG2 stromal antigen 2; ATR ataxia telangiectasia and Rad3 serine/threonine kinase; PRKDC protein kinase, DNA-activated, catalytic subunit 


\section{A $E G F R$}
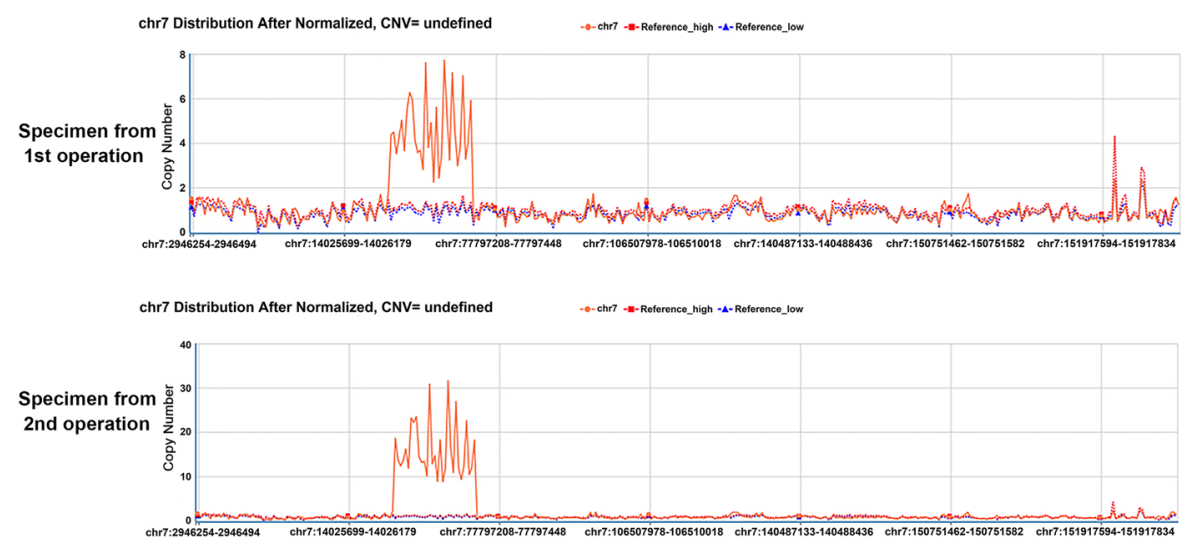

B PIK3CA: [Somatic Mutation Rate: 100\%] NM_006218

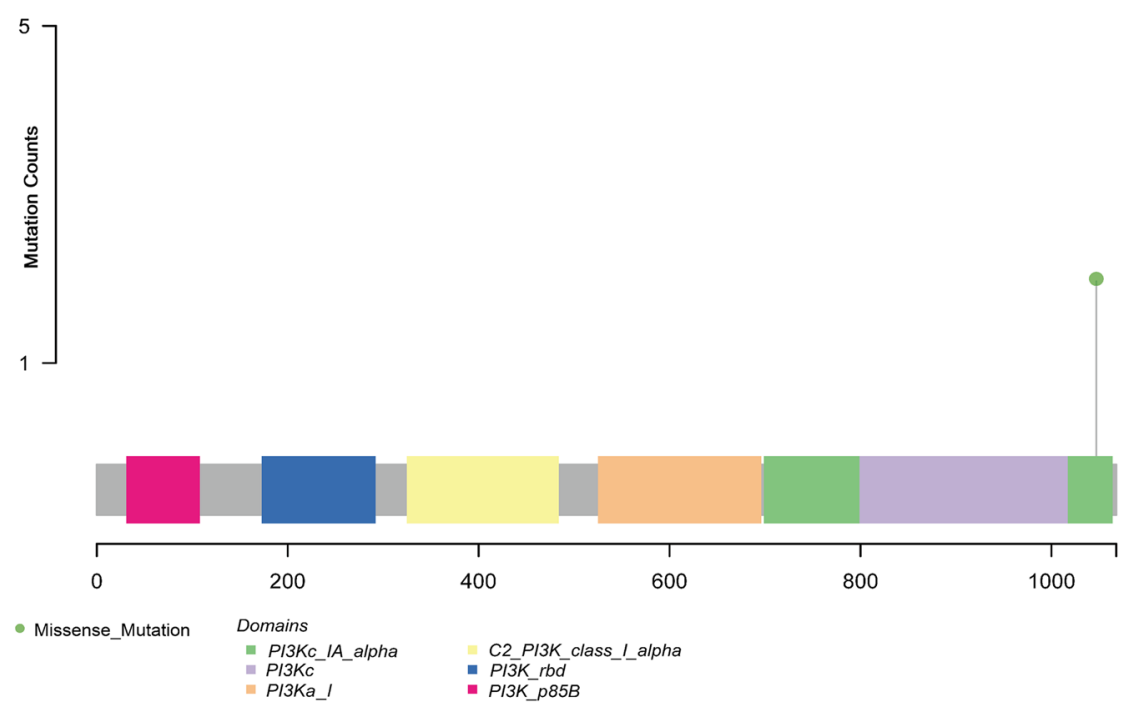

Fig. $\mathbf{5}$ a The proliferative mutation of EGFR. $\mathbf{b}$ The missense mutation of PIK3CA

Hematoxylin) and dehydrated. Both of the staining outcomes revealed the positive expression of G-CSF (Fig. 6).

\section{Discussion}

Renal tumor is rarely associated with ALR; only few papers reported several sporadic cases before [12-14]. ALR is probably caused by mechanical stimuli on bone marrow, resulting from bone metastases. They may also be caused by humoral stimuli resulting from neosynthesized blastic factors or factors released from the foci of tumor necrosis. Febrile sign is the clinical manifestation of ALR, possibly associated with paraneoplastic syndromes, resulting from either a release of endogenous pyrogens or tumor necrotic-inflammatory response [16], which decided the ineffectivity of antibiotic therapies.

Given the fact that RCC progression is usually accompanied with uncontrollable proliferation, distant metastasis, and recurrence, and the exact molecular mechanism of RCC is still unclear and needs to be further investigated, the genetic mutation analysis is becoming more and more important in the course of diagnosis and treatment for RCC. As for the outcome of postoperative tissue-originated comprehensive genomic profiling, the mutations of several vital oncogenes were indicated in this case. The EGFR/PIK3CA pathway has been reported as an important regulating role in the progression of RCC [17]. The expression of EGFR correlates with prognosis in patients with clear cell RCC [18], and 


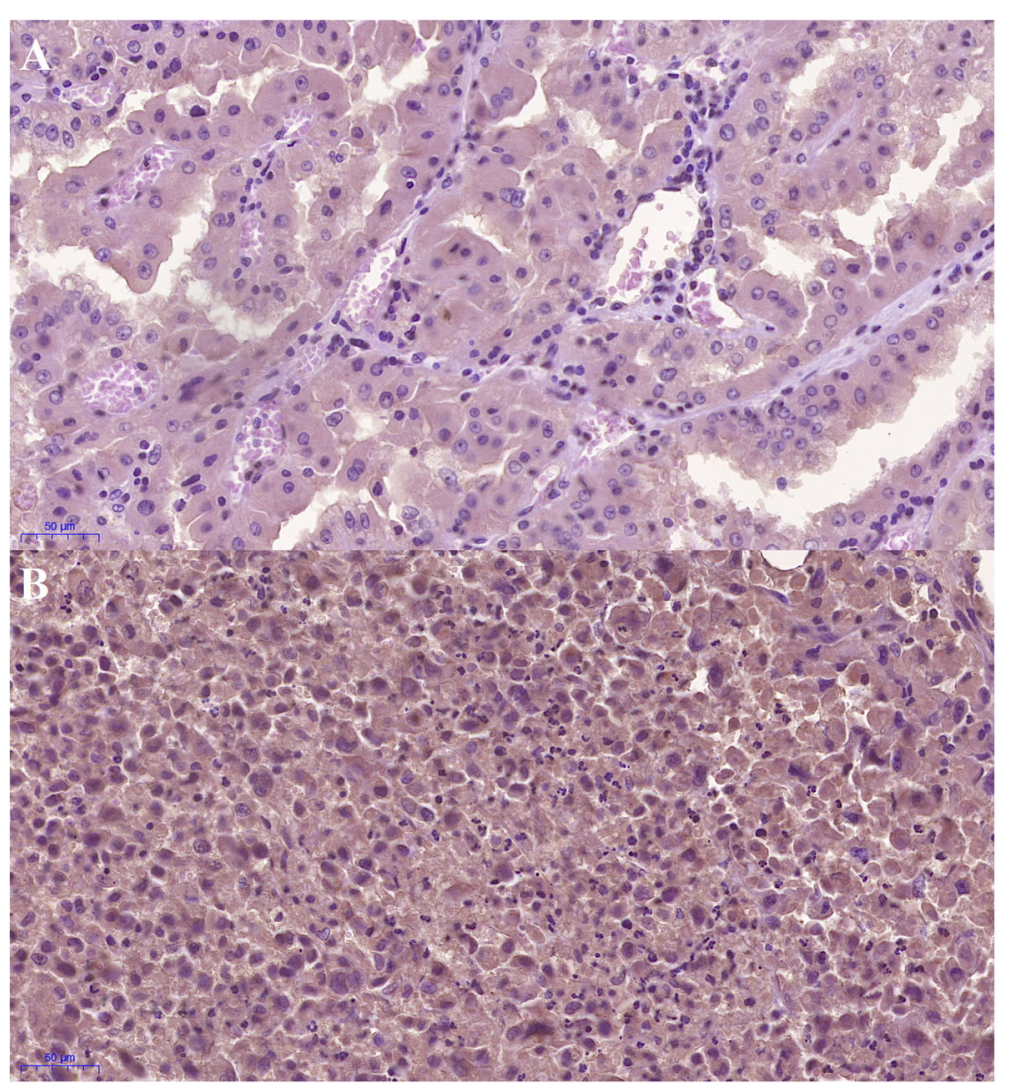

Fig. 6 The immunohistochemistry for assessment of G-CSF expression in the renal tumor and in the specimen from the reoperation. Both of the staining outcomes revealed the positive expression of G-CSF. a Immunopositive for G-CSF from the specimen of 1st operation. $\mathbf{b}$ Immunopositive for G-CSF from the specimen of 2nd operation

suppression of the EGFR signaling pathway can retard the tumor progression [19]. Moreover, the PIK3CA pathway is highly activated in RCC progression [20]. Ataxia telangiectasia and Rad3 Serine/Threonine Kinase (ATR) responds to a broader spectrum of DNA damage and replication interference, including single-stranded DNA (ssDNA), double-stranded DNA (dsDNA) adjacent to ssDNA, adducts, cross-links, and inhibition of DNA polymerase [21]. This signaling pathway has a central role in detecting DNA damage, regulating DNA repair, and coordinating with other cellular processes. Its mutation can lead to genome instability and cell death [22, 23]. Besides, protein kinase, DNA-activated, catalytic subunit (PRKDC), which is an important DNAdependent protein kinase catalytic subunit, has been reported the over-expression in multiple human RCC tissues, and its inhibition via pharmacological inhibitors or siRNA/shRNA knockdown can significantly reduce the RCC cell proliferation in vitro and in vivo [24].

As for the relevance between ALR and our genetic findings, we found that the increased copy number of EGFR is due to polyploidy of chromosome 7. The EGFR copy number gain in tumor cells is associated with increased mutant allele transcription and gene activity. $E G F R$ can activate the RAS/RAF/MEK pathway, which has a central role in the development and progression of cancer. A previous study reported that several growth factors including EGFR can induce G-CSF expression by a $R A S / R A F / M E K$-dependent mechanism, and the activation of the $R A S / R A F / M E K$ signaling pathway triggered by EGFR can result in enhanced G-CSF expression and induce neutrophil recruitment significantly [25]. Another study reported the extreme leukocytosis and leukemoid reaction in a patient with lung sarcomatoid carcinoma. He underwent surgery for resection of the mass, and immunohistochemistry showed the overexpression of $E G F R$, but the authors did not further explore the potential relevance between EGFR and leukemoid reaction in this case [26]. In this case, we speculated that the possible mechanism is the proliferative mutation of EGFR induced the activation of RAS/RAF/MEK pathway and resulted in the upregulation of G-CSF, which caused ALR eventually. Besides, the PI3K/AKT/mTOR signaling pathway plays a central role in a wide spectrum of cellular activities, including cell proliferation, survival, and differentiation. Missense mutation of PIK3CA pathway 
components are involved in tumor development and occur in many cancer types. A previous study reported that inhibition of PI3K signaling decreases the production of proinflammatory cytokines including G-CSF [27]. Another study reported that G-CSF can activate the PI3K-Akt pathway in human neutrophils [28]. We speculated the possible mechanism driving the paraneoplastic leukemoid reaction in our case is through the interaction between PIK3CA and G-CSF, inducing a leukocytosis. In this case, the high intratumoral G-CSF expression and secretion, interacting with many oncogenes including EGFR and PIK3CA, might play a central role in the induction of ALR and could be viewed as an adverse prognosticator.

On the other hand, we speculate that the carbon dioxide pneumoperitoneum may be a potential risk factor for the tumor recurrence in this case. It has been a controversial issue whether the laparoscopic pneumoperitoneum enhances the tumor metastasis. Many reports addressed different conclusions based on their own outcomes [29-32], and there is no consensus until now. This rare case reminds us that high nuclear grading, which indicates high-grade malignancy, should be a warning sign to avoid choosing the laparoscopic or retrolaparoscopic surgery in RCC patients.

\section{Conclusions}

ALR associated with overexpression of G-CSF may be a predictor of poor prognosis in patients with RCC, and comprehensive genomic profiling can help to provide potential valuable genetic etiological information and evidence for guiding the potential effective moleculartargeting therapy.

\section{Supplementary information}

Supplementary information accompanies this paper at https://doi.org/10. 1186/s12957-020-01926-4.

Additional file 1: Supplemental 1

Additional file 2: Supplemental 2 Surgical video

\section{Abbreviations}

ALR: Acute leukemoid reaction; RN: Radical nephrectomy; RCC: Renal cell carcinoma; WBC: White blood cell; CT: Computed tomography; RBC: Red blood cell; 3D-DM: Three-dimensional digital model

\section{Acknowledgements}

Not applicable.

\section{Authors' contributions}

XZ was the main surgeon of the operation and conceived of the study. LY collected the clinical data and participated in the coordination and drafted the manuscript. XY and LZ were the assistant surgeons of the operation. TB provided the pathological results and immunohistochemical outcomes. SH collected the information of postoperative comprehensive genomic profiling and reconstructed the three-dimensional digital model. All authors read and approved the final manuscript.

\section{Funding}

This study was funded by Innovation Team Fund Program of First Hospital of Shanxi Medical University (grant no.: YT1604), Fund Program for the Scientific Activities of Selected Returned Overseas Professionals in Shanxi Province (grant no.: [2018]-1059-6), Shanxi Provincial Basic Applied Research Project (grant no.: 201801D121331), and Scientific Research Program of Shanxi Provincial Health Commission (grant no.: 2017035). The funders had no influence on the analysis or publication.

\section{Availability of data and materials}

All data generated or analyzed during this study are included in this manuscript.

\section{Ethics approval and consent to participate}

The study was approved by the institutional ethics board of First Hospital of Shanxi Medical University and Shanxi Cancer Hospital.

\section{Consent for publication}

Written informed consent was obtained from the patient for the publication of this case report and any accompanying images.

\section{Competing interests}

The authors declare that they have no competing interests.

\section{Author details}

${ }^{1}$ Department of Urology, First Hospital of Shanxi Medical University, No. 85, Jiefangnan Road, Taiyuan 030001, Shanxi, China. ${ }^{2}$ Shanxi Cancer Institute, Shanxi Cancer Hospital, Taiyuan 030000, Shanxi, China. ${ }^{3}$ Department of Pathology, First Hospital of Shanxi Medical University, Taiyuan 030001, Shanxi, China.

Received: 6 November 2019 Accepted: 18 June 2020

Published online: 06 July 2020

References

1. Ljungberg B. Prognostic markers in renal cell carcinoma. Curr Opin Urol. 2007:17(5):303-8.

2. Siegel RL, Miller KD, Jemal A. Cancer statistics, 2017. CA Cancer J Clin. 2017; 67(1):7-30.

3. Hollingsworth JM, Miller DC, Daignault S, Hollenbeck BK. Rising incidence of small renal masses: a need to reassess treatment effect. J Natl Cancer Inst. 2006;98(18):1331-4

4. Smith ZL. Current status of minimally invasive surgery for renal cell carcinoma. Curr Urol Rep. 2016:17(6):43.

5. Hoffman R, Furie B, McGlave P, Silberstein LE, Shattil SJ, Benz EJ, Heslop H. Hematology: basic principles and practice. Volume 702. 5th edition. Philadelphia: Churchill Livingstone; 2009.

6. Riesenberg H, Müller F, Görner M. Leukemoid reaction in a patient with adenocarcinoma of the lung: a case report. J Med Case Rep. 2012;19(6):211.

7. Ma X, Li G, Cai Z, Sun W, Liu J, Zhang F. Leukemoid reaction in malignant bone tumor patients- a retrospective, single-institution study. Eur Rev Med Pharmacol Sci. 2012;16(14):1895-9.

8. Boşoteanu C, Boşoteanu M, Aşchie M. Differential diagnosis issues in a case of gastric carcinoma associated with leukemoid reaction. Rom J Morphol Embryol. 2009:50(4):701-5.

9. Perez FA, Fligner CL, Yu EY. Rapid clinical deterioration and leukemoid reaction after treatment of urothelial carcinoma of the bladder: possible effect of granulocyte colony-stimulating factor. J Clin Oncol. 2009;27(34): e215-7.

10. Saussez S, Heimann P, Vandevelde L, Bisschop P, Jortay A, Schandene L, Cogan E. Undifferentiated carcinoma of the nasopharynx and leukemoid reaction: report of case with literature review. J Laryngol Otol. 1997;111: 66-9.

11. Qureshi KM, Raman AK, Tan D, Fakih MG. Leukemoid reaction in pancreatic cancer: a case report and review of the literature. JOP. 2006; 7(6):631-4.

12. Huang W, Wang F, Li Y, Duan F, Yu Z. Leukemoid reaction in sarcomatoid renal cell carcinoma: a two-case report. World J Surg Oncol. 2014; 12:100. Wang YC, Yang S, Tzen CY, Lin CC, Lin J. Renal cell carcinoma producing granulocyte colony-stimulating factor. J Formos Med Assoc. 2006;105(5): 414-7. 
13. Sato T, Yamauchi N, Kobayashi D, Sato Y, Mochizuki C, Hori C, Watanabe N, Niitsu Y. Granulocyte colony stimulating factor (G-CSF) producing renal cell carcinoma. Rinsho Ketsueki. 1997;38(11):1189-93.

14. Galia M, Albano D, Bruno A, Agrusa A, Romano G, Di Buono G, Agnello F, Salvaggio G, La Grutta L, Midiri M, Lagalla R. Imaging features of solid renal masses. Br J Radiol. 2017;90(1077):20170077.

15. Sakka V, Tsiodras S, Giamarellos-Bourboulis EJ, Giamarellou H. An update on the etiology and diagnostic evaluation of a leukemoid reaction. Eur J Intern Med. 2006;17(6):394-8.

16. Liu F, Shangli Z, Hu Z. CAV2 promotes the growth of renal cell carcinoma through the EGFR/PI3K/Akt pathway. Onco Targets Ther. 2018;11:6209-16.

17. Dorđević G, Matušan Ilijaš K, Hadžisejdić I, Maričić A, Grahovac B, Jonjić N. EGFR protein overexpression correlates with chromosome 7 polysomy and poor prognostic parameters in clear cell renal cell carcinoma. J Biomed Sci. 2012;19:40.

18. Liang L, Li L, Zeng J, Gao Y, Chen YL, Wang ZQ, Wang XY, Chang LS, He D. Inhibitory effect of silibinin on EGFR signal-induced renal cell carcinoma progression via suppression of the EGFR/MMP-9 signaling pathway. Oncol Rep. 2012;28(3):999-1005.

19. Zhao Z, Liu H, Hou J, Li T, Du X, Zhao X, Xu W, Xu W, Chang J. Tumor protein D52 (TPD52) inhibits growth and metastasis in renal cell carcinoma cells through the PI3K/Akt signaling pathway. Oncol Res. 2017;25(5):773-9.

20. Zou L. Single- and double-stranded DNA: building a trigger of ATRmediated DNA damage response. Genes Dev. 2007:21:879-85.

21. Cimprich KA, Cortez D. ATR: an essential regulator of genome integrity. Nat Rev Mol Cell Biol. 2008;9(8):616-27.

22. Abraham RT. Cell cycle checkpoint signaling through the ATM and ATR kinases. Genes Dev. 2001;15(17):2177-96.

23. Zheng B, Mao JH, Li XQ, Qian L, Zhu H, Gu DH, Pan XD. Over-expression of DNA-PKcs in renal cell carcinoma regulates mTORC2 activation, HIF-2a expression and cell proliferation. Sci Rep. 2016:6:29415.

24. Phan VT, Wu X, Cheng JH, Sheng RX, Chung AS, Zhuang G, Tran C, Song Q, Kowanetz M, Sambrone A, Tan M, Meng YG, Jackson EL, Peale FV, Junttila MR, Ferrara N. Oncogenic RAS pathway activation promotes resistance to anti-VEGF therapy through G-CSF-induced neutrophil recruitment. Proc Natl Acad Sci U S A. 2013;110(15):6079-84.

25. Wang D, Zhang H, Yu F, Fang B. Extreme leukocytosis and leukemoid reaction associated with the lung sarcomatoid carcinoma: an unusual case report. Int J Gen Med. 2016;10:7-9.

26. Xie $\mathrm{S}$, Chen $\mathrm{M}$, Yan B, He X, Chen X, Li D. Identification of a role for the PIJK/AKT/mTOR signaling pathway in innate immune cells. PLoS One. 2014; 9(4):e94496.

27. Kamata N, Kutsuna H, Hato F, Kato T, Oshitani N, Arakawa T, Kitagawa S. Activation of human neutrophils by granulocyte colony-stimulating factor, granulocyte-macrophage colony-stimulating factor, and tumor necrosis factor a: role of phosphatidylinositol 3-kinase. Int J Hematol. 2004;80(5):421-7.

28. Lin F, Pan L, Li L, Li D, Mo L. Effects of a simulated CO2 pneumoperitoneum environment on the proliferation, apoptosis, and metastasis of cervical cancer cells in vitro. Med Sci Monit. 2014;20:2497-503.

29. Ishida H, Hashimoto D, Nakada H, Takeuchi I, Hoshino T, Murata N, Idezuki Y, Hosono M. Increased insufflation pressure enhances the development of liver metastasis in a mouse laparoscopy model: possible mechanisms. Surg Endosc. 2002;16(2):331-5.

30. Zheng L, Zhou D, Lu L, Liu Z, Fang L. Effects of $\mathrm{CO}_{2}$ pneumoperitoneum on proliferation, apoptosis, and migration of gastrointestinal stromal tumor cells. Surg Endosc. 2019:33(10):3384-95.

31. Azuar AS, Matsuzaki S, Darcha C, Déchelotte PJ, Pouly JL, Mage G, Canis M. Impact of surgical peritoneal environment on postoperative tumor growth and dissemination in a preimplanted tumor model. Surg Endosc. 2009;23(8):1733-9.

32. Zhang X, Guo X, Zhang A, Wang Y, Zhao J. Influence of carbon dioxide pneumoperitoneum environment on adhesion and metastasis of a human ovarian cancer cell line. Surg Endosc. 2009;23(1):108-12.

\section{Publisher's Note}

Springer Nature remains neutral with regard to jurisdictional claims in published maps and institutional affiliations.

\section{Ready to submit your research? Choose BMC and benefit from:}

- fast, convenient online submission

- thorough peer review by experienced researchers in your field

- rapid publication on acceptance

- support for research data, including large and complex data types

- gold Open Access which fosters wider collaboration and increased citations

- maximum visibility for your research: over $100 \mathrm{M}$ website views per year

At $\mathrm{BMC}$, research is always in progress.

Learn more biomedcentral.com/submissions 